\title{
IMPLEMENTATION OF CONSISTENT PILKADA IN MALANG REGENCY IN 2020 FROM PRECAUTIONARY PRINCIPLES
}

\author{
Fitria Esfandiari ${ }^{1}$, Arsyi Manggali Arya Putra ${ }^{2}$ \\ 1,2 Faculty of Law, University of Muhammadiyah Malang, Indonesia, fit.esfan@gmail.com \\ (corresponding)
}

\begin{abstract}
The implementation of the Regional Head Election (Pilkada) which was held simultaneously on December 9, 2020 in Malang Regency is a step towards realizing democracy directly in the region. In contrast to the implementation of pilkada in previous years, this year's regional elections were held in the midst of the Covid 19 pandemic. With the issuance of PKPU Number 5 of 2020, it was decided to continue. This research raises the problem of how the simultaneous regional elections in Malang Regency are viewed from the principle of precautionary and how to project the strengthening of democracy through simultaneous regional elections in Malang Regency. The method used is the descriptive normative method by reviewing literature that is in line with existing problems with statutory regulations as well as statutory approaches and literature. The conclusion from this research is that the stages of the Pilkada implementation which are carried out with the principle of precautionary are an effort to limit the spread of the Covid 19 virus. On the other hand, it is also an effort to continue to fulfill the constitutional rights of the people in the regions in the Pilkada. Furthermore, if it is related to the simultaneous regional election scheme in 2027, Malang Regency in its development is able to play a very significant role for democracy in the regions with. The technology and information approach must be seen as an effort to solve democracy in the regions in the pandemic era.
\end{abstract}

Keywords: Democracy; Pilkada; Precautionary Principle

\section{INTRODUCTION}

The history of state administration in Indonesia from 1967 to 1998, namely for thirty-two years recorded reforms in the constitution.(MD, 2015) In the narrow understanding that the constitution is equated with the 1945 Constitution, there have been four amendments (Asshidiqie, 2009). There are two important political instruments that become policies, namely democratic elections and regional autonomy or decentralization policies. In its development, the regional head elections which aim to elect regional heads are an indicator of the success of democracy (Tjenreng, 2016). 
Fitria Esfandiari, Arsyi Manggali Arya Putra

pp. 11-18
E-ISSN : 2723-2476

ISSN : 2723-1968

ACLJ, Vol. 2, Issue 1, 2021

Indonesia as a legal country with the highest sovereignty is in the hands of the people.(Esfandiari, 2020). Regional head elections or abbreviated Pilkada are part of the implementation of democracy in Indonesia (Ali Syafaat, 2011). The desire of the government and political elites to continue to carry out the election stages is contrary to the real conditions in society.(Fadli, 2017) A serious problem that must be considered is the increasing number of positive patients with Covid 19. Not to mention the risk of its spread if it is carried out with campaigns and crowds. Two choices are taken, namely to continue with strict protocols or be postponed (Kennedy $\&$ Suhendarto, 2020). The General Election Commission (KPU) provides a legal basis for carrying out campaign activities. Through PKPU of the Republic of Indonesia No. 13 of 2020, Article 1 paragraphs $28,29,30,33$, and 34 regulate campaign policies during a pandemic. The aim is to test the public's trust that the campaign does not bring the masses (Indradi et al., 2020).And accompanied by PKPU Article $88 \mathrm{C}$ paragraph 2 confirms that there is a written warning and dissolution from Bawaslu if a candidate pair, campaign team, and other parties violate the provisions of Article $88 \mathrm{C}$ paragraph 1.

The government provides a legal rule for the implementation of Pilkada, in article 8B PKPU Number 5 of 2020, stating that, "The implementation of simultaneous voting which was postponed due to the non-natural disaster CoronaVirus Disease 2019 (Covid-19), was held on December 9, 2020". This means that the democratic party in Malang Regency during this pandemic period will continue to be carried out. Even though there were many criticisms and input from various circles in the community.

Malang Regency, which is in the region of East Java Province, is one of the regency that carries out direct Pilkada on December 9, 2020 (Farisa, 2020). The Ministry of Home Affairs and DPR RI Commission II have discussed and determined that the Pilkada in Malang Regency will continue to be implemented. using implementing health protocols.(Ristyawati, 2020). This study aims to find solutions to these problems while still following the government's decision to continue implementing the campaign and maintaining public trust by numbering safety from the spread of the plague in the implementation stages of regional head elections in Malang Regency. The implementation of the constitutional rights of Malang Regency residents by the Malang Regency Government, on the one hand, refers to the health protocol and the precautionary principle of preventing Covid 19.

1. How is the simultaneous Pilkada implementation in Malang Regency in terms of the precautionary principle?

2. What is the projection of strengthening democracy through simultaneous regional elections in Malang Regency?

\section{METHODOLOGY}

The approach method used by the author in this study is a normative juridical approach (legal research).(Marzuki, 2010) Regarding the election of regional heads in Malang Regency. The legal materials used by the author in this study were obtained from primary legal materials, namely Law Number 7 of 2017 concerning General Elections, PKPU Number 13 of 2020 and PKPU Number 5 of 2020. Secondary legal materials are library materials containing information about the main material (Soekanto, 2017). The collection of legal materials is done by looking for references related to 
problems in the implementation of the elections. Thus it is expected to produce accountable conclusions and then analyzed using descriptive methods.

\section{RESULT AND DISCUSSION}

\section{Implementation of Simultaneous Pilkada in Malang Regency in Terms of the Precautionary Principle}

Regional head elections which are held simultaneously in various regions in Indonesia are a step towards realizing democracy directly (Nurhasim, 2018). At the regional level, the election of a regional leader reflects the realization of the people's sovereignty as the holder of the highest sovereignty (Pardede, 2018). The Regional Head Election (Pilkada) was held simultaneously on December 9, 2020 in Malang Regency. If analyzed the Government Regulation in Lieu of Law Number 2 of 2020 concerning the Third Amendment to Law Number 1 of 2015 concerning Stipulation of Government Regulations in Lieu of Law Number 1 of 2014 concerning the Election of Governors, Regents and Mayors into Law (Perpu No 2 of 2020) has provided a legal basis for the implementation of Pilkada in 2020, the voting was conducted in December 2020. If the Pilkada is held there is potential for the spread of Covid 19. The government will carry out the Pilkada simultaneously on the legal basis stated in Article 201 paragraph (1) of the law number 10/2016 concerning the Second Amendment to law number 1 of 2015 concerning Stipulation of Government Regulations in Lieu of Law Number 1 of 2014 concerning the Election of Governors, Regents and Mayors Into Law (Law No.10 of 2016), that In December 2015 the Pilkada was held simultaneously for the first time. In accordance with the term of office of the regional government which is 5 (five) years, in 2020 the terms of office for regional heads and deputy regional heads should end.

The precautionary principle used in this study is closely related to the principles commonly used in banking mechanisms. The precautionary principle is a principle which states that in carrying out its business functions and activities, banks are obliged to apply the precautionary principle in order to protect public funds. the community entrusted him. With the implementation of the precautionary principle, it is hoped that the level of public trust in banking will remain high, so that the public is willing and does not hesitate to deposit their funds in the bank. The author's note relates the principle of banking precautionary with the urgency of the elections in Malang Regency. Referring to the precautionary principle above, this principle is related to the level of public trust. If it is related to the implementation of Pilkada in Malang Regency, the organizers are Bawaslu or KPU Kabupaten Malang organizing this Pilkada using the principle of precautionary in order to realize the good trust of the people of Malang Regency. Law Number 23/1997 concerning on the Law on Environmental Protection and Management there are no provisions regarding the precautionary principle.(Purwendah, 2019) In Article 3 of the UUPLH, it is stated that the principles, goals and objectives of environmental management only mention the principle of state responsibility, the principle of sustainability and the principle of benefit which aims to realize sustainable development with an environmental perspective.

In terminology, the precautionary principle is used in the process of updating voter data.(Malang, 2020) This is because the election process involves three functions. First, the function 
of the election administrator is the administrative recording of election participants. Second, the administrative function of voters, so that no citizen loses his / her right to vote. Third, in relation to the results of the regional elections, it must include the entirety of the voting and counting processes. The stages of updating and compiling voter lists based on PKPU number 5 of 2020 concerning the Third Amendment to General Election Commission Regulation Number 15 of 2019 concerning Stages, Programs and Schedules for Organizing the Election of Governors and Deputy Governors, Regents and Deputy Regents, and / or Mayors and Deputy Mayors The City of 2020 consists of the preparation of the Voters List by the Regency / City KPU and submitting it to PPS, as well as updating.

There is no specific regulation regarding this precautionary principle even though Indonesia has actually ratified 2 conventions, namely the Ratification of the Rio de Jeneiro Conference which contains the precautionary principle through Law Number 5/1995 concerning Ratification of the United Nations Conventos on Biological Diversity and Law Number 6/1996 concerning Ratification of the United Nations Framework Convention on Climate Change. So Indonesia actually applies the principle of precautionary in both banking and environmental aspects. This pattern is one of the best solutions in a pandemic like this. Apart from that, there are other problems for example money politics. This condition gave many negative impacts in the implementation of Pilkada in Malang Regency.

It should be understood that this precautionary principle is used as a guideline for the implementation of Pilkada in Malang Regency. If the rules are implemented responsively, then the law can run as a function according to Mochtar Kusuma Adtmaja that "the law must be used as a means to solve problems in state administration" (Kusumaatmadja, 2002).

\section{Projection of Strengthening Democracy in The Regions Through Digital Platforms.}

Democracy in its development no longer only relies on the idea of how the people can participate in running the country. Democracy with its development thus leads to an even more complex form of participation, and is not as simple as that in classical democratic thought. Democracy thus raises two major views on it, namely classical democracy and contemporary democracy as found in political science literature. According to classical democracy theory, it has three meanings at once, namely (Ali \& Noor, 2019)

1. Democracy as a source of state authority, which is in the midst of the people, or is the power of the people

2. Democracy is the goal of the government to provide for the needs of democracy as a method for selecting political leaders by the people.

3. Democracy as a method for electing political leaders by the people.

Jimly Asshidiqie translated democracy, one of which is the power that comes from the people. (Asshidiqie, 2009)). Democracy as an idea of governance based on the people. The people are often mentioned as the owners of government administration when referring to a democratic perspective. The word democracy itself appeared in the 5th century BC (Przeworski, 2010).

Functionally, democracy is defined as the value of a good life (good society), as a pattern of social interaction, and as public policy as a compromise of conflict or interaction of interests. 
Honestly (fairness), are non-independent (liberty), fair (justice), equality (equality), fraternity (brotherhood), and the various rights of the individual and social, is the basic values of democracy (Sisk, 2017). Cooperation between local authorities with the community movement is very necessary because it creates mutually reinforcing and supportive relationships. John Stuart Mill and supporters of participatory democracy at the local level argue that opening the tap for policy and public intelligence will support the creation of good governance and support the achievement of social welfare. Thus, the goal of democracy is to create harmony between the government and society, to build a society that has a social spirit.

As mentioned above, in relation to Pilkada, fundamental changes occurred after June 1, 2015 with the direct regional head election mechanism. Historically, this step was taken as a consequence of the representative system which was deemed not fulfilling democratic values. The regional head was previously determined by the DPRD members.

Democracy in Malang Regency through the 2020 Pilkada must go hand in hand with the community. This means that the contribution of the Malang Regency community in the Pilkada is very influential on the Pilkada. In the implementation of democracy through Pilkada, the participation of all people in elections is not the main condition, what is more important is openness to all parties. Today many people are indifferent to politics which is part of democracy. The most important value is an open system, where there are not many obstacles for people to show dislike. Pilkada in Malang Regency must continue to run so that the democracy of Malang Regency society runs well. Even though the conditions in the midst of the current pandemic are a challenge for the Regional Government and the people of Malang Regency.

The current condition must find a new breakthrough for the implementation of Pilkada to run democracy in Malang Regency. Currently, there are many ways that people use to play a role in local politics (Pilkada) which are more flexible. Today, social media and print media are very close to the general public, so they are widely used to exploit their interests, including political campaigns. Today, social media and print media are very close to the general public, so they are widely used to take advantage of their interests, including political campaigns (Solihah, 2018),

In theory, digital technology allows leaders to engage in a new level of "conversation" with voters, changing campaigning has become something more dynamic, more of a dialogue, than in the 20th century (Ardha, 2014). Almost all political parties in Indonesia have official websites that are specially managed by the media center. Due to its long span of time, social media does not have a significant impact on mobilizing campaigns. The nature of a campaign on social media can be the opposite of a campaign in the real world. If in the real world the campaign is so noisy, loud but without real evidence, on social media is the antithesis of noise and noise, that is meaningful. Every sound has a meaning, has its proof individually.

Online campaigns have a fairly high level of vulnerability to breaches of blogs or platforms used in the campaign (Karlsen, 2013). On the other hand, online media can also be used for measure the extent to which the public participation and media activities of every citizen in politics (Strandberg, 2014). So the government must provide security certainty in the campaign. First, the need to work closely with the Ministry of Communication and Informatics to track accounts of the 
spread of black campaigns, etc., especially at this time, Kominfo collaborates a lot with communities and the private sector who are also engaged in monitoring social media content such as the Indonesian Anti-Defamation Society (Mafindo), Cyberkreasi, Drones Emprit, and others. Second, Bawaslu can work with representatives of social media application providers in Indonesia to minimize the spread of hoaxes and negative content during the campaign period. Third, Bawaslu can work together with civil society organizations that participate in monitoring the emergence of false information, hate speech, politicizing SARA, disinformation, and others to do fact checking during the campaign period (Perdana \& Wildianti, 2019). With the online campaign. Pilkada in Malang Regency runs according to the general election corridor and democracy in Malang Regency continues to live as it should. If it is related to the simultaneous regional election scheme in 2027 and after this year there will only be two elections, namely the national election consisting of legislative and presidential elections and regional head elections. Malang Regency in its development is able to play a very significant role for democracy in the regions.

\section{CONCLUSION}

The Malang Regency Pilkada was held on December 9, 2020. The precautionary principle is recognized and used in banking mechanisms. if linked to the election process, this principle is applied in the voter data updating process. This means starting from the administrative data collection of election participants, voter administration to the entire voting and counting process. this is related to the level of public trust.. In the other hand, In the digital age as today, using a digital platform at this stage of the election process is one solution. along with the implementation of health protocols to prevent the spread of Covid 19. Online platform can also be used as a form of public participation in regional election activities

\section{REFERENCES}

Ali, N., \& Noor, S. (2019). Pendidikan Islam Multikultur: Relevansi, Tantangan, dan Peluang. Jurnal Hadratul Madaniyah. https://doi.org/10.33084/jhm.v6i1.879

Ali Syafaat, M. (2011). Pembubaran Partai Politik Pengaturan dan Praktik Pembubaran Partai Politik dalam Pergulatan Republik. Jakarta: Rajawali Press.

Ardha, B. (2014). Social Media sebagai media kampanye partai politik 2014 di Indonesia. Visi Komunikasi.

Asshidiqie, J. (2009). Hukum Tata Negara dan Pilar-Pilar Demokrasi. Serpihan Pemikiran Hukum, Media Dan HAM.

Esfandiari, F. (2020). INITIATING A PERMANENT ELECTORAL BODY TO RESOLVE DIGNIFIED ELECTION DISPUTES: ASSESSING THE EFFECTIVENESS OF GAKKUMDU. Yustisia Jurnal Hukum, 9(3), 333-347. Retrieved from https://jurnal.uns.ac.id/yustisia/article/view/44437

Fadli, M. (2017). Constitutional recognition and legal protection for local religion in Indonesia: A 
discourse on local religion of the tengger and baduy people. Pertanika Journal of Social Sciences and Humanities, 25(2), 601-614.

Farisa, F. C. (2020). Ketua KPU: Pilkada Tetap Desember 2020, Tidak Akan Mundur Lagi.

Retrieved June 17, 2020, from Kompas.com website:

https://nasional.kompas.com/read/2020/05/28/23194681/ketua-kpu-pilkada-tetap-desember2020-tidak-akan-mundur-lagi?page=all

Indradi, A. R. I. S. A. H., Arsyah, A. M., Mulyani, C. K., Athilla, K. D., Faruq, M. H. Al, Rayhan, M., ... Dinda, S. (2020). Politik Hukum Pemerintah dalam Penanganan Pandemi Covid-19. Universitas Gajah Mada.

Karlsen, R. (2013). Obama's Online Success and European Party Organizations: Adoption and Adaptation of U.S. Online Practices in the Norwegian Labor Party. Journal of Information Technology and Politics. https://doi.org/10.1080/19331681.2012.749822

Kennedy, R., \& Suhendarto, B. P. (2020). Diskursus Hukum: Alternatif Pola Pengisian Jabatan Kepala Daerah di Masa Pandemi Covid-19. Jurnal Pembangunan Hukum Indonesia. https://doi.org/10.14710/jphi.v2i2.188-205

Kusumaatmadja, M. (2002). Konsep-Konsep Hukum Dalam Pembangunan - Fungsi dan Perkembangan Hukum Dalam Pembangunan Nasional. Teori Hukum Pembangunan.

Malang, K. K. (2020). Kehati-hatian Dalam Pemuktakhiran dan Penyusunan Daftar Pemilih. Retrieved from 12 Oktober website: http://kpud-malangkota.go.id/berita/kehati-hatian-dalampemutakhiran-dan-penyusunan-daftar-pemilih

Marzuki, P. M. (2010). Penelitian Hukum Revised Edition. Jakarta: Kencana Prenada Media Grup.

MD, M. M. (2015). ASPEK HUKUM NEGARA DAN ADMINISTRASI NEGARA KELEMBAGAAN PENGADILAN PAJAK. Jurnal Hukum Dan Peradilan. https://doi.org/10.25216/jhp.4.3.2015.351-360

Nurhasim, M. (2018). Konstelasi politik di tahun elektoral. JUrnal Penelitian Politik, 15(No 2), $129-142$.

Pardede, M. (2018). Legitimasi Pemilihan Kepala/Wakil Kepala Daerah dalam Sistem Pemerintahan Otonomi Daerah. Jurnal Penelitian Hukum De Jure. https://doi.org/10.30641/dejure.2018.v18.127-148

Perdana, A., \& Wildianti, D. (2019). Narasi Kampanye dan Media Sosial dalam Pemilu Presiden dan Wakil Presiden Tahun 2019. Jakarta: Bawaslu RI.

Przeworski, A. (2010). Consensus, conflict, and compromise in western: Thought on representative government. Procedia - Social and Behavioral Sciences. 
Fitria Esfandiari, Arsyi Manggali Arya Putra pp. 11-18
E-ISSN : 2723-2476

ISSN : 2723-1968

ACLJ, Vol. 2, Issue 1, 2021

https://doi.org/10.1016/j.sbspro.2010.05.058

Purwendah, E. (2019). Precautionary Principle Through the Obligations of Marine Insurance for Oil Tankers in the Indonesian Legal System. https://doi.org/10.4108/eai.10-9-2019.2289415

Ristyawati, A. (2020). EFEKTIVITAS PELAKSANAAN PILKADA SERENTAK 2020 PADA MASA PANDEMI DARURAT COVID-19 DI INDONESIA. CREPIDO. https://doi.org/10.14710/crepido.2.2.85-96

Sisk, T. D. (2017). Elections, Electoral Systems and Party Systems a Resource Guide. Electoral Systems and Party Systems.

Soekanto, S. (2017). PENELITIAN HUKUM DAN PENDIDIKAN HUKUM. Jurnal Hukum \& Pembangunan. https://doi.org/10.21143/jhp.vol6.no6.716

Solihah, R. (2018). Peluang dan tantangan pemilu serentak 2019 dalam perspektif politik. Jurnal Ilmiah Ilmu Pemerintahan, 3(1), 73-88. https://doi.org/10.14710/jiip.v3i1.3234

Strandberg, K. (2014). Mapping the Online Campaign Audience: An Analysis of Online Participation and Its Mobilizing Potential in the 2011 Finnish Parliamentary Campaign. Journal of Information Technology and Politics. https://doi.org/10.1080/19331681.2014.895475

Tjenreng, M. B. Z. (2016). Democratic System Strengthening Through Concurrent Election Implementation To Improve Political Stability and National Development. Journal of Social and Development Sciences. https://doi.org/10.22610/jsds.v7i2.1306 